\title{
ANALISIS PERENCANAAN DAN PENGANGGARAN UNTUK ANGGARAN PENDAPATAN DAN BELANJA DAERAH PADA BADAN KEUANGAN KABUPATEN KEPULAUAN SANGIHE TAHUN ANGGARAN 2015
}

\author{
Dealice Ivana Barbakem ${ }^{1}$, Jantje J. Tinangon ${ }^{2}$, Harijanto Sabijono ${ }^{3}$ \\ 1,2,3 Jurusan Akuntansi, Fakultas Ekonomi dan Bisnis, Universitas Sam Ratulangi, Kampus Unsrat Bahu \\ Malalayang, Kota Manado, 95115, Indonesia \\ E-mail : dealiceiv@gmail.com
}

\begin{abstract}
Planning and budgeting is a part which cannot be seperated from the proccess of government financial management. Need for integrity against a schedule of planning and budgeting Anggaran Pendapatan dan Belanja Daerah (APBD), linkages planning document that one against the other, as well as effective and efficient local government solutions to constrains in the planning and budgeting of the previous fiscal year APBD to be implemented in the next fiscal year. Badan Keuangan Kabupaten Kepulauan Sangihe is a functional government part that has the task of carrying out the affairs of local governance best on the principle of autonomy and helper task in the areas of income, asset and financial management areas, so that the operations of the system of government financial arrangements in particular regions can be run well. The purpose of this research was to determine whether the proccess of planning and budgeting for Anggaran Pendapatan dan Belanja Daerah (APBD) on Badan Keuangan Kabupaten Sangihe fiscal year 2015 is in compliance with Permendagri Nomor 13 Tahun 2006.This research uses descriptive research method. The research results showed of 14 steps, 1 of which shows the time and discrepancy functions according to Permendagri Nomor 13 Tahun 2006.
\end{abstract}

Keywords : Planning, Budgeting, Regional Expenditure.

\section{PENDAHULUAN}

Undang-Undang Nomor 9 tahun 2015 dinyatakan bahwa otonomi daerah adalah kewenangan daerah untuk mengatur dan mengurus kepentingan masyarakat setempat menurut prakarsa sendiri berdasarkan aspirasi masyarakat dalam ikatan Negara Kesatuan Republik Indonesia. Dengan otonomi daerah tersebut, pemerintah daerah memiliki kebebasan untuk membuat inisiatif sendiri, mengelola dan mengoptimalkan sumber daya daerah. Adanya kebebasan untuk berinisiatif merupakan suatu dasar pemberian otonomi daerah, karena dasar pemberian otonomi daerah adalah dapat berbuat sesuai dengan kebutuhan daerah setempat.

Salah satu bagian penting dari mekanisme pengelolaan keuangan daerah adalah perencanaan dan penganggaran daerah. Ini merupakan bagian yang tidak dapat dipisahkan karena saling berkaitan. . Perencanaan dan penganggaran merupakan dua hal yang sangat diperlukan untuk mengelola pembangunan daerah secara efektif dan efisien. Agar berjalan baik, sebaiknya penganggaran tidak mendikte proses perencanaan, dan sebaiknya perencanaan perlu mempertimbangkan ketersediaan dana dan kelayakan ekonomi agar realistis.

Produk akhir (output) dari suatu perencanaan dan penganggarannya adalah dalam bentuk dokumen perencanaan dan penganggaran secara tertulis yang disusun dengan peraturan perundang-undangan yang berlaku. Pada pemerintah daerah hasil dari perencanaan dan penganggaran adalah dokumen Anggaran Pendapatan dan Belanja Daerah (APBD) yang disusun pada setiap tahun anggaran. 
Perlu adanya integritas terhadap jadwal dari perencanaan dan penganggaran Anggaran Pendapatan dan Belanja Daerah (APBD) sesuai dengan batas waktu yang tertera dalam Permendagri Nomor 13 Tahun 2006 bab IV bagian kedua hingga bagian keenam tentang langkah-langkah dan jadwal perencanaan serta penganggaran APBD, keterkaitan dokumen perencanaan yang satu terhadap yang lain, serta efektif dan efisienkah solusi pemerintah daerah untuk kendala dalam perencanaan dan penganggaran APBD tahun anggaran sebelumnya untuk dilaksanakan ditahun anggaran selanjutnya. Dewasa ini, hasil evaluasi menunjukan sikap yang mengabaikan ketepatan waktu pelaksanaan dan keterkaitan antar dokumen perencanaan menyebabkan pelaksanaan kegiatan dan penganggaran menjadi tidak konsisten. Hal ini dapat menyebabkan tidak semua perencanaan program dan penyusunan anggaran untuk meningkatan pelayanan publik berjalan dengan baik sesuai dengan jadwal yang ditetapkan dan ketepatan fungsi dana tersebut. Tujuan penelitian ini adalah untuk mengetahui apakah proses Penyusunan Perencanaan dan Penganggaran untuk Anggaran Pendapatan dan Belanja Daerah pada Badan Keuangan Kabupaten Kepulauan Sangihe Tahun Anggaran 2015 sudah sesuai dengan Permendagri Nomor 13 Tahun 2006.

\section{TINJAUAN PUSTAKA}

\subsection{Konsep Pengelolaan Keuangan Daerah.}

Dalam Permendagri Nomor 13 Tahun 2006 disebutkan bahwa defenisi keuangan daerah adalah semua hak dan kewajiban daerah dalam rangka penyelenggaraan pemerintahan daerah yang dapat dinilai dengan uang termasuk didalamnya segala bentuk kekayaan yang berhubungan dengan hak dan kewajiban tersebut. Menurut Ratmono \& Sholihin (2015:5) pengelolaan keuangan daerah adalah seluruh kegiatan yang meliputi perencanaan, pelaksanaan, penatausahaan, pelaporan, pertanggungjawaban dan pengawasan keuangan daerah. Proses pengelolaan keuangan daerah dapat dibagi menjadi 4 tahap yaitu:

\subsubsection{Perencanaan dan Penganggaran}

Pada tahap ini dilakukan aktifitas yang berurutan yaitu: (1) penyusunan dan pengesahan Kebijakan Umum APBD (KUA), (2) penyusunan dan pengesahan Prioritas dan Plafon Anggaran Sementara (PPAS), (3) penyusunan dan pengesahan, penyusunan dan pengesahan Rencana Kerja dan Anggaran Satuan Kerja Perangkat Daerah (RKA-SKPD) dan (4) penyusunan dan pengesahan perda APBD.

\subsubsection{Pelaksanaan dan Penatausahaan Anggaran Pendapatan dan Belanja Daerah} (APBD)

Pada tahap ini terdapat beberapa kegiatan pengelolaan keuangan daerah seperti penyusunan Dokumen Pelaksanaan Anggaran (DPA) SKPD dan anggaran kas, penyediaan dana, pengajuan Surat Permintaan Pembayaran (SPP), penerbitan Surat Perintah Membayar (SPM), penerbitan Surat Perintah Pencairan Dana (SP2D), pembelanjaan dana dan pertanggungjawaban dana.

\subsubsection{Perubahan Anggaran Pendapatan dan Belanja Daerah (APBD)}

Perubahan APBD dapat dilakukan apabila terjadi:

1) Perkembangan yang tidak sesuai asumsi KUA;

2) Keadaan yang menyebabkan harus dilakukan pergeseran antar unit organisasi, antar kegiatan, dan antar jenis belanja;

3) Keadaan yang menyebabkan saldo anggaran lebih tahun sebelumnya harus digunakan dalam tahun berjalan;

4) Keadaan darurat; dan

5) Keadaan luar biasa.

Pada tahap perubahan APBD ini dilakukan beberapa kegiatan seperti penyusunan KUA dan PPAS Perubahan APBD, penyusunan RKA SKPD perubahan APBD, 
penyusunan dan pengesahan Perubahan APBD, penyusunan dan pengesahan Dokumen Pelaksanaan Perubahan Anggaran (DPPA) SKPD.

\subsection{Ciri-ciri Perencanaan Pembangunan Daerah yang Baik}

Dikemukakan juga oleh Pekei (2016:23) ciri-ciri perencanaan pembangunan daerah yang baik adalah:

1) Punya target yang jelas.

Satu daerah dengan daerah lain mempunyai target yang berbeda yang tercantum dalam Renstra (Rencana Strategi) daerah masing-masing. Perencanaan baik apabila dari target yang dimiliki mempunyai langkah-langkah yang jelas untuk melaksanakannya.

2) Konsisten dan realistis.

Yang sering terjadi adalah berbeda antara apa yang direncanakan dengan apa yang dikerjakan sehingga pekerjaan tidak sesuai lagi dengan perencanaan yang dibuat dan disetujui bersama. Perencanaan juga harus mengukur sumber daya yang dimiliki, sehingga perencanaan yang dibuat bukanlah yang tidak mungkin dilaksanakan.

3) Mempunyai pengawasan yang kontinyu.

Dengan alur dan sistem yang jelas sehingga perencanaan akan menjadi alat kontrol yang kontinyu.

4) Jelas target fisik dan pembiayaan.

Perencanaan harus mempunyai target pencapaian apa yang dikerjakan termasuk kualitas dan persyaratan secara fisik lainnya. Disamping itu perencanaan juga jelas target anggarannya.

5) Terukur.

Sehingga dalam pelaksanaannya memudahkan menentukan indikator keberhasilannya.

6) Ada batas waktu yang jelas dari setiap pekerjaannya.

\subsubsection{Proses Perencanaan Pembangunan Daerah}

Perencanaan tidak muncul dengan sendirinya tetapi harus disusun secara sistematis melalui beberapa proyeksi menurut Pekei (2016:24) yakni:

1) Penentuan tujuan (goal setting).

Tujuan merupakan akhir dari sebuah rencana. Tujuan mempunyai lima hal yang dikenal dengan SMART (Suistainable, Measurable, Achievable, Realitic, Timely).

2) Penentuan target.

Target merupakan serangkaian kegiatan dan tujuan. Misalnya tujuan dari suatu daerah adalah meningkatkan kesejahteraan masyarakat, maka targetnya bisa berupa penurunan angka kemiskinan, penurunan angka pengangguran, meningkatkan investasi, pengurangan laju inflasi dan seterusnya.

3) Mengetahui posisi awal perencanaan.

Mengetahui dimana, berapa posisi sumber daya yang dimiliki, kekuatan pendukung, tantangan, peluang, dan seterusnya.

4) Punya alternatif.

5) Perencanaan tidak boleh hanya ada satu. Karena kondisi sosial ekonomi yang selalu berubah. Oleh karena itu harus selalu ada pilihan pada kondisi tertentu atau terjadinya perubahan variable ekonomi.

6) Menyusun rangkaian langkah untuk mencapai tujuan.

Menyusun perencanaan pembangunan daerah menjadi suatu hal yang wajib bagi daerah, sehingga ada istilah "rencanakan pekerjaan dan kerjakan rencana". Ada daerah yang mampu melakukan perencanaan dengan baik tapi tidak mampu melaksanakan rencananya, sehingga perencanaan hanya menjadi dokumen yang tidak mempunyai makna. Begitupun juga dengan program-program pembangunan daerah, banyak yang dilakukan namun tidak konsisten dalam menjalankannya. 


\subsection{Konsep Penganggaran Pemerintah Daerah}

Menurut Pekei (2016:13) anggaran pemerintah atau yang disebut dengan Anggaran Pendapatan dan Belanja Negara (APBN) dan Anggaran Pendapatan dan Belanja Daerah (APBD) yang dikelola oleh pemerintah, maka anggaran adalah pernyataan tentang estimasi kinerja yang akan dicapai selama periode tertentu yang dinyatakan dalam ukuran finansial atau uang. Dalam proses penyusunan anggaran disebut penganggaran, maka penganggaran disusun harus berdasarkan kepada kepentingan organisasi sektor publik, dalam penyusunan anggaran oleh pemerintah merupakan tahap yang cukup luas karena tidak hanya mempertimbangkan ekonomi tetapi juga terhadap faktor sosial politik yang semakin kental dalam organisasi masyarakat. Penganggaran pada pemerintah terkait dengan penentuan jumlah alokasi dana untuk tiap-tiap program atau aktivitas yang akan dilakukan dalam satu moneter, untuk itu ada beberapa aspek yang harus dipenuhi dalam penyusunan anggaran pemerintah adalah aspek perencanaan, aspek pengendalian, serta aspek transparansi dan akuntabilitas secara umum. Dalam penyusunan anggaran pemerintah mempunyai beberapa prinsip anggaran pemerintah yaitu:

1. Penguasaan otoritas oleh legislatif, adalah anggaran harus mendapatkan persetujuan terlebih dahulu oleh legislatif sebelum anggaran tersebut dibelanjakan oleh pemerintah/eksekutif.

2. Komprehensif atau data yang benar, adalah anggaran harus memuat seluruh penerimaan dan pengeluaran pemerintah.

3. Keutuhan anggaran, adalah seluruh penerimaan dan pengeluaran pemerintah harus didata dan terhimpun dalam dana umum atau dalam kas anggaran pemerintah.

4. Penghematan, adalah jumlah anggaran yang disetujui oleh legislatif harus digunakan oleh eksekutif secara ekonomis, efisien dan efektif.

5. Periodik atau bertahap, adalah anggaran harus disusun dalam jangka waktu tertentu yaitu jangka waktu pendek, jangka waktu menengah dan jangka waktu panjang.

6. Teratur dan akurat, adalah anggaran penerimaan dan pengeluaran harus disusun secara teratur sehingga tidak terjadi penurunan pendapatan atau berlebihan pengeluaran.

7. Jelas atau clear estimate, adalah anggaran harus disusun secara jelas, sederhana dan mudah dipahami oleh pengguna dan masyarakat.

8. Transparan dan terbuka, adalah anggaran disusun secara terbuka atau transparan serta dapat diketahui dengan mudah oleh masyarakat umum.

\subsection{Penelitian Terdahulu}

1. Korompot 2015) meneliti tentang Analisis Penyusunan Anggaran pada Dinas Pendapatan, Pengelolaan Keuangan dan Aset Daerah Kota Kotamobagu Tahun Anggaran 2014. Metode penelitian yang digunakan adalah metode deskriptif kualitatif. Hasil penelitian menunjukan Dinas Pendapatan, Pengelolaan Keuangan dan Aset Daerah Kota Kotamobagu dalam pelaksanaan penyususnan anggaran tahun anggaran 2014 telah sesuai dengan Permendagri No. 27 Tahun 2013.

2. Suwaryono (2014) meneliti tentang Rembug Anggaran dalam Perencanaan Penganggaran Daerah: Gabus Utawi Sae-Saen (Studi Kasus dalam Penganggaran Daerah di Pemerintah Kabupaten Boyolali). Metode penelitian yang digunakan adalah penelitian deskriptif kualitatif dan hasil penelitian menunjukan Musrenbang Desa di wilayah Kab.Boyolali sekarang lebih partisipatif dengan ditandai banyaknya masyarakat yang hadir dalam Musrenbang Desa.Musrenbang Kecamatan di wilayah Kab.Boyolali diadakan dalam 2 hari, namun masih terdapat Kecamatan yang mempersingkatnya menjadi 2 hari. Menurut peserta Musrenbang Kecamatan, kegiatan ini terkesan hanya untuk formalitas demi memenuhi mekanisme perencanaan pembangunan. 
Musrenbang Kabupaten di Kab.Boyolali difasilitasi oleh Bappeda setempat dan sesuai dengan perundang-undangan yang berlaku. Masih terdapat penyimpangan dalam Musrenbang Kabupaten menjadi evaluasi penting untuk tahun anggaran selanjutnya.

\section{METODE PENELITIAN}

\subsection{Jenis Penelitian}

Jenis penelitian yang digunakan adalah penelitian deskriptif. Penelitian deskriptif artinya mengumpulkan data, disusun, diinterprestasikan dan dianalisis sehingga memberikan kesimpulan yang jelas dan objektif terhadap masalah yang ada.

\subsection{Tempat dan Waktu Penelitian}

Tempat penelitian bertempat di Badan Keuangan Kabupaten Kepulauan Sangihe. Waktu penelitian sejak bulan Maret-April 2017.

\subsection{Metode Pengumpulan Data}

Metode yang digunakan untuk memperoleh data dengan melaksanakan studi lapangan adalah sebagai berikut:

1) Interview/Wawancara

Interview/wawancara dilaksanakan dengan melakukan tanya jawab langsung terhadap pihak-pihak yang bersangkutan guna mendapatkan data dan keterangan yang berlandaskan pada tujuan penelitian.

2) Dokumentasi

Dokumetasi dilakukan dengan melakukan pengumpulan data-data dan dokumen.

\subsection{Metode Analisis}

Metode yang digunakan untuk menganalisa data adalah deskriptif yang dimulai dengan mengumpulkan dan menyaring semua data yang masuk secara menyeluruh dan mendetail, kemudian diuraikan agar dapat diperoleh gambaran yang jelas. Langkah selanjutnya ialah penulis mengevaluasi pelaksanaan serta penerapan dari Perencanaan dan Penganggaran untuk Anggaran Pendapatan dan Belanja Daerah (APBD) pada Badan Keuangan Kabupaten Kepulauan Sangihe Tahun Anggaran 2015, kemudian dianalisis hingga ditemukan suatu kesimpulan dari permasalahan yang dipelajari.

\section{HASIL ANALISIS DAN PEMBAHASAN}

\subsection{Hasil analisis}

1. Perencanaan Anggaran Pendapatan dan Belanja Daerah (APBD)

\section{a. Penyusunan Rencana Kerja Pemerintah Daerah (RKPD)}

RKPD Kabupaten Kepulauan Sangihe menggambarkan permasalahan pembangunan daerah serta indikasi daftar program dan kegiatan yang akan dilaksanakan, untuk memecahkan permasalahan pembangunan daerah secara terencana melalui sumber pembiayaan yaitu APBD. Penyusunan RKPD di Kabupaten Kepulauan Sangihe secara keseluruhan menggunakan pendekatan teknoratis dan partisipatif. Pendekatan teknoratis dilaksanakan dengan menggunakan metode dan kerangka berpikir ilmiah, yang dilakukan melibatkan semua pihak yang berkepentingan (stakeholders) terhadap pembangunan daerah. Pendekatan partisipatif diwujudkan dengan pelaksanaan Musyawarah Perencanaan Pembangunan (Musrembang) yang dilakukan berjenjang mulai tingkat kelurahan, kecamatan ke tingkat kabupaten bahkan sebelum Musrembang yang pelaksanaannya ditekankan di tingkat RT/RW yang bertujuan untuk menjaring seluruh aspirasi lapisan masyarakat.

Tabel 1. Jadwal dan Pelaksanaan Penyusunan RKPD

\begin{tabular}{|c|c|c|c|}
\hline Tahapan Penyusunan APBD & Jadwal & Realisasi & Keterangan \\
\hline Penyusunan RKPD & Akhir Mei 2014 & 29 Mei 2014 & Tepat waktu \\
\hline
\end{tabular}

Sumber: Badan Keuangan Kab.Kepulauan Sangihe 
2. Penganggaran Anggaran Pendapatan dan Belanja Daerah (APBD)

a. Penyampaian Rancangan Kebijakan Umum APBD (KUA) dan Rancangan Prioritas Plafon Anggaran Sementara (PPAS)

Untuk menyusun KUA dan PPAS, Bupati Kabupaten Kepulauan Sangihe mengeluarkan Surat Edaran yang disampaikan kepada setiap Kepala Satuan Kerja Perangkat Daerah (SKPD). Surat Edaran Bupati yang dimaksud disiapkan oleh Tim Anggaran Pemerintah Daerah (TAPD) bekerjasama dengan Badan Pengelolaan Keuangan Daerah yang isisnya memuat permintaan kepada setiap SKPD agar menyusun dan menyampaikan Pra Rencana Kegiatan dan Anggaran (Pra RKA-SKPD) yang akan dijadikan bahan untuk menyusun Kebijakan Umum Anggaran (KUA) serta Prioritas dan Plafon Anggaran Sementara (PPAS). Setelah Rancangan KUA dan PPAS selesai disusun oleh TAPD menurut bentuk dan materi yang telah ditetapkan, perwakilan dari Tim sebagai pemimpin dalam hal ini Sekretaris Daerah menyerahkan dan menyampaikan kedua dokumen tersebut kepada Kepala Daerah atau Bupati yang selanjutnya dengan melalui mekanisme administrasi yang telah ditetapkan. Untuk membahas dokumen tersebut, yang pertama-tama dibahas oleh Tim Anggaran Pemerintah Daerah dan Badan Anggaran DPRD adalah Rancangan Kebijakan Umum Anggaran (KUA). Setelah KUA selesai dibahas kemudian ditetapkan, selanjutnya TAPD bersama Panitia Anggaran DPRD membahas Rancangan Prioritas dan Plafon Anggaran Sementara (PPAS), karena PPAS disusun berdasarkan KUA. Tabel ini menunjukan jadwal penyusunan dokumen KUA dan PPAS yang dijadwalkan serta realisasinya:

Tabel 2. Jadwal dan Pelaksanaan Penyusunan KUA dan PPAS

\begin{tabular}{|l|c|c|c|}
\hline \multicolumn{1}{|c|}{ Tahapan Penyusunan APBD } & Jadwal & Realisasi & Keterangan \\
\hline $\begin{array}{l}\text { Penyampaian Rancangan KUA } \\
\text { dan Rancangan PPAS oleh } \\
\text { Kepala Daerah kepada DPRD }\end{array}$ & $\begin{array}{c}\text { Minggu pertama } \\
\text { Bulan Juni 2014 }\end{array}$ & 6 Juni 2014 & Tepat waktu \\
- Rancangan KUA dan & & & \\
$\begin{array}{l}\text { Rancangan PPAS disepakati } \\
\text { antara Kepala Daerah dan }\end{array}$ & Akhir Bulan Juli & & \\
DPRD & 2014 & Tepat waktu \\
\hline
\end{tabular}

Sumber: Badan Keuangan Kab.Kepulauan Sangihe

b. Penyusunan Rencana Kerja Anggaran (RKA) - Satuan Kerja Perangkat Daerah (SKPD)

Rencana Kerja dan Anggaran Satuan Kerja Perangkat Daerah (RKA-SKPD) disampaikan oleh setiap Kepala SKPD kepada Badan Keuangan. Berikut tabel proses penyusunan Rancangan Kerja Anggaran (RKA-SKPD) Kabupaten Kepulauan Sangihe:

Tabel 3. Jadwal dan Pelaksanaan Penyusunan RKA-SKPD

\begin{tabular}{|l|c|c|c|}
\hline Tahapan Penyusunan APBD & Jadwal & Realisasi & Keterangan \\
\hline - Surat edaran Kepala Daerah perihal & Awal Bulan & 2 Agustus 2014 & Tepat waktu \\
Pedoman RKA-SKPD dan RKA- & Agustus 2014 & & \\
PPKD & & & Tepat waktu \\
- Penyusunan dan pembahasan & Awal Agustus sd & 2 Agustus sd 30 & \\
RKA-SKPD dan RKA-PPKD & Akhir September & September 2014 & \\
serta penyusunan rancangan & 2014 & & \\
APBD & & & \\
\hline
\end{tabular}

Sumber: Badan Keuangan Kab.Kepulauan Sangihe 
c. Penyusunan Rancangan Anggaran Pendapatan dan Belanja Daerah (RAPBD)

Penyusunan RKA-SKPD diterima oleh Kepala Badan Keuangan Daerah Sangihe. Rancangan peraturan daerah tentang APBD yang telah disusun oleh Badan Keuangan Daerah disertai dengan Nota Keuangan disampaikan kepada Bupati oleh Sekretaris Daerah selaku Ketua Tim Anggaran Pemerintah Daerah (TAPD) dan selanjutnya Bupati Kepulauan Sangihe menyerahkan Rancangan Peraturan Daerah tentang APBD dimaksud kepada DPRD setelah disosialisasikan kepada masyarakat oleh Sekretaris Daerah. Sosialisasi ini diadakan untuk mendiskusikan muatan atau materi dalam RAPBD yang sudah siap diserahkan untuk dibahas pada tingkat DPRD. Sosialisasi ini dihadiri oleh tokoh-tokoh masyarakat yang meliputi berbagai kalangan, seperti tokoh pemuda, tokoh pendidikan, lembaga swadaya masyarakat dan unsur masyarakat lainnya yang dianggap perlu. Berikut ini adalah tabel jadwal dan realisasi Penyampaian Rancangan APBD :

Tabel 4. Jadwal dan Pelaksanaan Penyampaian RAPBD

\begin{tabular}{|l|ll|c|c|}
\hline \multicolumn{1}{|c|}{ Tahapan Penyusunan APBD } & \multicolumn{2}{|c|}{ Jadwal } & Realisasi & Keterangan \\
\hline Penyampaian Rancangan APBD & Minggu Pertama & 3 Oktober 2014 & Tepat waktu \\
kepada DPRD & $\begin{array}{l}\text { Bulan Oktober } \\
2014\end{array}$ & & \\
\hline
\end{tabular}

Sumber: Badan Keuangan Kab.Kepulauan Sangihe

\section{d. Pembahasan dan Persetujuan Rancangan Anggaran Pendapatan dan Belanja Daerah (RAPBD)}

Berikut adalah tabel jadwal dan pelaksanaan pembahasan serta penetapan RAPBD :

Tabel 5. Jadwal dan Realisasi Pembahasan dan Penetapan RAPBD

\begin{tabular}{|c|c|c|c|}
\hline Tahapan Penyusunan APBD & Jadwal & Realisasi & Keterangan \\
\hline $\begin{array}{l}\text { Pengambilan persetujuan } \\
\text { bersama DPRD dan Kepala } \\
\text { Daerah }\end{array}$ & $\begin{array}{c}\text { Maksimal } 1 \text { bulan } \\
\text { sebelum tahun } \\
\text { anggaran yang } \\
\text { ditentukan }\end{array}$ & $\begin{array}{l}25 \text { November } \\
2014\end{array}$ & Tepat waktu \\
\hline $\begin{array}{l}\text { - Hasil evaluasi Rancangan } \\
\text { APBD }\end{array}$ & $\begin{array}{c}15 \text { hari kerja } \\
\text { (Bulan Desember) }\end{array}$ & 23 Desember 2014 & Tidak tepat waktu \\
\hline $\begin{array}{l}\text { - Penetapan Perda APBD dan } \\
\text { Perkada Penjabaran APBD } \\
\text { sesuai dengan hasil evaluasi }\end{array}$ & $\begin{array}{l}\text { Paling lambat } \\
\text { akhir Desember } \\
\text { (31 Desember) }\end{array}$ & 31 Desember 2014 & Tepat waktu \\
\hline
\end{tabular}

Sumber: Badan Keuangan Kab.Kepulauan Sangihe

Penetapan Peraturan Daerah Kabupaten Kepulauan Sangihe tentang APBD dan Penetapan Peraturan Bupati tentang Penjabaran APBD dengan diberlakukannya Peraturan Pemerintah Nomor 58 Tahun 2005 adalah APBD Tahun Anggaran 2015 ditetapkan dengan Peraturan Daerah Nomor 10 Tahun 2014, tanggal 31 Desember 2014. Dengan ditetapkannya kedua dokumen anggaran ini, menandakan bahwa seluruh proses perencanaan dan penganggaran untuk APBD dianggap telah selesai dan memasuki tahap pelaksanaan. 
Tabel 6. Tabel Penyesuaian Jadwal dan Realisasi

Proses Perencanaan dan Penganggaran APBD

\begin{tabular}{|c|c|c|c|c|}
\hline No & Uraian & Dijadwalkan & Terealisasi & Keterangan \\
\hline 1. & Penyusunan RKPD & $\begin{array}{l}\text { Akhir bulan Mei } \\
2014\end{array}$ & 29 Mei 2014 & Tepat waktu \\
\hline 2. & $\begin{array}{l}\text { Penyampaian Rancangan KUA dan } \\
\text { Rancangan PPAS oleh Ketua } \\
\text { TAPD kepada Kepala Daerah }\end{array}$ & $\begin{array}{l}\text { Minggu pertama } \\
\text { Bulan Juni } 2014\end{array}$ & 6 Juni 2014 & Tepat waktu \\
\hline 3. & $\begin{array}{l}\text { Penyampaian Rancangan KUA dan } \\
\text { Rancangan PPAS oleh Kepala } \\
\text { Daerah kepada DPRD }\end{array}$ & $\begin{array}{l}\text { Pertengahan Bulan } \\
\text { Juni } 2014\end{array}$ & 16 Juni 2014 & Tepat waktu \\
\hline 4. & $\begin{array}{c}\text { Rancangan KUA dan Rancangan } \\
\text { PPAS disepakati antara Kepala } \\
\text { Daerah dan DPRD } \\
\end{array}$ & $\begin{array}{l}\text { Akhir Bulan Juli } \\
2014\end{array}$ & 30 Juli 2014 & Tepat waktu \\
\hline 5. & $\begin{array}{c}\text { Surat edaran Kepala Daerah perihal } \\
\text { pedoman RKA-SKPD dan RKA- } \\
\text { PPKD }\end{array}$ & $\begin{array}{l}\text { Awal Bulan } \\
\text { Agustus } 2014\end{array}$ & $\begin{array}{l}2 \text { Agustus } \\
2014\end{array}$ & Tepat waktu \\
\hline 6. & $\begin{array}{c}\text { Penyusunan dan pembahasan RKA- } \\
\text { SKPD dan RKA-PPKD serta } \\
\text { Penyusunan Rancangan APBD }\end{array}$ & $\begin{array}{c}\text { Awal Bulan } \\
\text { Agustus sampai } \\
\text { akhir September } \\
2014\end{array}$ & $\begin{array}{l}2 \text { Agustus } \\
\text { sampai } 30 \\
\text { September } \\
2014\end{array}$ & Tepat waktu \\
\hline 7. & $\begin{array}{c}\text { Penyampaian Rancangan APBD } \\
\text { kepada DPRD }\end{array}$ & $\begin{array}{c}\text { Minggu pertama } \\
\text { bulan Oktober } 2014\end{array}$ & $\begin{array}{l}3 \text { Oktober } \\
2014\end{array}$ & Tepat waktu \\
\hline 8. & $\begin{array}{l}\text { Pengambilan persetujuan bersama } \\
\text { DPRD dan Kepala Daerah }\end{array}$ & $\begin{array}{l}\text { Paling lama } 1 \text { bulan } \\
\text { sebelum tahun } \\
\text { anggaran yang } \\
\text { ditentukan }\end{array}$ & $\begin{array}{l}25 \text { November } \\
2014\end{array}$ & Tepat waktu \\
\hline 9. & Hasil evaluasi Rancangan APBD & $\begin{array}{l}15 \text { hari kerja (Bulan } \\
\text { Desember) } 2014\end{array}$ & $\begin{array}{l}23 \text { Desember } \\
2014\end{array}$ & $\begin{array}{l}\text { Tidak tepat } \\
\text { waktu }\end{array}$ \\
\hline 10. & $\begin{array}{c}\text { Penetapan Perda APBD dan } \\
\text { Perkada Penjabaran APBD sesuai } \\
\text { dengan hasil evaluasi }\end{array}$ & $\begin{array}{l}\text { Paling lambat akhir } \\
\text { Desember (31 } \\
\text { Desember) } 2014\end{array}$ & $\begin{array}{l}31 \text { Desember } \\
2014\end{array}$ & Tepat waktu \\
\hline
\end{tabular}

Sumber: Badan Keuangan Kab.Kepulauan Sangihe

\subsection{Pembahasan}

1. Analisis Perencanaan Anggaran Pendapatan dan Belanja Daerah (APBD)

Dalam rangka penyusunan Anggaran Pendapatan dan Belanja Daerah (APBD) pada tingkat pemerintah daerah, pemerintah pusat dalam hal ini Kementrian Dalam Negeri setiap tahunnya mengeluarkan Permendagri (Peraturan Menteri Dalam Negeri) tentang pedoman Penyusunan APBD agar menjadi pedoman pemerintah daerah. Peraturan Menteri Dalam Negeri (Permendagri) Nomor 37 Tahun 2014 menjadi acuan Pemerintah Kabupaten Kepulauan Sangihe dan seluruh daerah-daerah di Indonesia dalam menyusun perencanaan APBD tahun anggaran 2015 yang memuat:

1. Pokok-pokok kebijakan yang memuat sinkronisasi kebijakan pemerintah dengan pemerintah daerah;

2. Prinsip dan kebijakan penyusunan APBD tahun anggaran berkenan;

3. Teknis penyusunan APBD;

4. Hal-hal khusus yang lain.

Sedangkan untuk pedoman pengelolaan keuangan daerah, dalam tahapan dan jadwal penyusunan APBD, peraturan yang digunakan adalah Permedagri Nomor 13 Tahun 2006 yang berlaku sampai tahun anggaran penelitian ini diangkat yaitu tahun 2015. Dalam 
Permendagri tersebut dijelaskan tahapan penyusunan dan jadwal APBD yang akan dibahas dalam bab ini secara detail.

\section{Penyusunan Rencana Kerja Pemerintah Daerah (RKPD)}

Proses Penyusunan APBD biasanya mengikuti peraturan pemerintah pusat yang adalah pemerintah tingkat tertinggi sebagai perpanjangan wewenang penyelenggaraan negara dari tingkat pusat. Sebagai contoh salah satu perumusan strategi dan perencanaan strategis pemerintah pusat yang dilakukan oleh negara adalah dibuatnya Program Pembangunan Nasional (PROPENAS) sebagai acuan dalam penyusunan APBN. Sementara ditingkat pemerintahan daerah salah satunya adalah Rencana Pembangunan Jangka Menengah Daerah (RPJMD) yang mengacu pada Program Pembangunan Nasional (PROPENAS) selama 5 tahun, kemudian Rencana Pembangunan Tahunan Daerah (RAPETADA) yang sekarang dinamakan sebagai RKPD (Rencana Kerja Pemerintah Daerah) untuk rencana pembangunan setiap tahun yang menjadi dasar dalam penyusunan program kerja APBD. Oleh sebab itu dalam tahapan perencanaan Anggaran Pendapatan dan Belanja Daerah (APBD) Kabupaten Kepulauan Sangihe dimulai dengan penyusunan Rencana Kerja Pemerintah Daerah (RKPD) oleh setiap Satuan Kerja Perangkat Daerah (SKPD) di instansi-instansi pemerintahan Kabupaten. Penyusunan RKPD ini masuk dalam proses perencanaan APBD karena setiap instansi pemerintahan wajib memasukan rencana program yang sesuai dengan jobdes yang akan disaring dan diputuskan menjadi program kerja APBD tahun bersangkutan.

\section{Analisis Penganggaran Anggaran Pendapatan dan Belanja Daerah (APBD)}

Penganggaran adalah bagian dari perencanaan. Penganggaran adalah metode untuk mempersiapkan kematangan Anggaran Pendapatan dan Belanja Daerah (APBD) sebelum disahkan. Penganggaran merupakan proses mengalokasikan atau memutuskan alokasi sumber daya untuk kegiatan prioritas. Dengan demikian, perencanaan dan penganggaran menjadi suatu yang sangat penting dalam penyelenggaraan pemerintahan di daerah karena merupakan rangkaian kegiatan dalam satu kesatuan. Proses penganggaran Anggaran Pendapatan dan Belanja Daerah (APBD) adalah sebagai berikut:

a. Penyampaian Rancangan Kebijakan Umum APBD (KUA) dan Rancangan Prioritas dan Plafon Anggaran Sementara (PPAS)

Ini adalah langkah selanjutnya setelah penyusunan Rencana Kerja Pemerintah Daerah (RKPD) karena pada proses ini, Pemerintah dalam hal ini diwakilkan oleh Tim Anggaran Pemerintah Daerah (TAPD) menyusun kebijakan umum APBD (KUA) yang bertujuan agar jika nanti masa transisi antara kebijakan APBD tahun berjalan dan tahun berikutnya terjadi, pemerintah dapat mengestimasi pengeluaran publik. Selain itu dari proses penyusunan KUA dan PPAS ini dapat membangun kerjasama antara Tim Anggaran Pemerintah Daerah (TAPD) dan Bupati Kepulauan Sangihe, Satuan Kerja Pemerintah Daerah (SKPD), dan pihak legislatif dalam hal ini Dewan Perwakilan Rakyat Daerah (DPRD) Kepulauan Sangihe yang menjadi pihak-pihak berkaitan dalam penetapan KUA dan PPAS. Harapannya kerja sama yang baik tercermin dari penggunaan tanggungjawab dan otoritas yang benar sebagai pemimpin yang punya andil dalam penetapan kebijakan dan batas atas anggaran, dengan menghindari tekanan berlebihan dari orang-orang yang mementingkan kepentingan sendiri daripada masyarakat.

b. Penyusunan Rencana Kerja Anggaran (RKA) - Satuan Kerja Perangkat Daerah (SKPD)

Dokumen penyusunan anggaran yang disampaikan oleh masing-masing Satuan Kerja Perangkat Daerah (SKPD) sesuai dengan program-program yang direncanakan disusun dalam format Rencana Kerja dan Anggaran (RKA) SKPD. RKA-SKPD disusun dengan harapan dapat menyajikan informasi yang jelas tentang tujuan, sasaran, serta korelasi 
antara besaran anggaran (beban kerja dan harga satuan) dengan manfaat dan hasil yang ingin dicapai atau diperoleh masyarakat dari suatu kegiatan yang dianggarkan masingmasing SKPD.

c. Penyusunan Rancangan Anggaran Pendapatan dan Belanja Daerah (RAPBD)

RKA-SKPD yang telah disusun, dibahas, dan disepakati bersama antara Kepala SKPD dan Tim Anggaran Pemerintah Daerah (TAPD) digunakan sebagai dasar untuk penyiapan Raperda APBD. Raperda ini disusun oleh pejabat pengelola keuangan daerah yang untuk selanjutnya disampaikan kepada Bupati Kepulauan Sangihe. Selanjutnya sebelum Bupati menyerahkan dokumen Raperda kepada DPRD untuk dibahas, sebaiknya di sosialisasikan dahulu kepada masyarakat dari tingkat Desa/Kelurahan hingga Kecamatan oleh Sekretaris Daerah, agar pemerintah daerah serta masyarakat mengetahui informasi tentang hak dan kewajiban masing-masing kapasitas dalam pelaksanaan APBD pada tahun anggaran 2015.

d. Pembahasan dan Persetujuan Rancangan Anggaran Pendapatan dan Belanja Daerah (RAPBD)

Menurut ketentuan dari Pasal 104 Permendagri No. 13 Tahun 2006, Raperda beserta lampiran-lampirannya yang telah disusun dan disosialisasikan kepada masyarakat untuk selanjutnya disampaikan oleh kepala daerah kepada DPRD paling lambat pada minggu pertama bulan Oktober tahun anggaran sebelumnya dari tahun anggaran yang direncanakan untuk mendapatkan persetujuan bersama. Pengambilan keputusan bersama ini harus sudah terlaksana paling lama 1 bulan sebelum tahun anggaran yang bersangkutan dimulai. Raperda APBD tersebut antara lain memuat rencana pengeluaran yang telah disepakati bersama. Raperda APBD ini baru dapat dilaksanakan oleh pemerintahan Kabupaten Kepulauan Sangihe setelah mendapat pengesahan dari Gubernur Provinsi Sulawesi Utara. Langkah ini akan terdiri dari 3 proses yaitu pengambilan persetujuan bersama DPRD dan Kepala Daerah, Hasil evaluasi Rancangan APBD, dan Penetapan Perda APBD dan Perkada Penjabaran APBD sesuai dengan hasil evaluasi. Ditemukan adanya keterlambatan pada proses evaluasi Rancangan APBD dalam Sidang Paripurna dengan Gubernur Sulawesi Utara. Ini disebabkan karena dalam Sidang mengevaluasi Rancangan APBD ini, seluruh Kabupaten/Kota harus dibahas bergiliran sesuai dengan urutan pemasukan dokumen RAPBD kepada pemerintah provinsi untuk dibahas dalam sidang Paripurna. 


\begin{tabular}{|c|c|c|c|}
\hline \multicolumn{4}{|c|}{ Tabel 7. Tahapan dan Jadwal Perencanaan dan Penganggaran APBD } \\
\hline NO & URAIAN & WAKTU & KET \\
\hline 1. & Penyusunan RKPD & Akhir bulan Mei & \\
\hline 2. & $\begin{array}{l}\text { Penyampaian Rancangan KUA dan Rancangan PPAS } \\
\text { oleh Ketua TAPD kepada Kepala Daerah }\end{array}$ & $\begin{array}{ll}\text { Minggu } \\
\text { bulan Juni }\end{array}$ pertama & 1 minggu \\
\hline 3. & $\begin{array}{l}\text { Penyampaian Rancangan KUA dan Rancanga PPAS oleh } \\
\text { Kepala Daerah kepada DPRD }\end{array}$ & $\begin{array}{l}\text { Pertengahan bulan } \\
\text { Juni }\end{array}$ & \\
\hline 4. & $\begin{array}{l}\text { Kesepakatan antara Kepala Daerah dan DPRD atas } \\
\text { Rancangan KUA dan Rancangan PPAS }\end{array}$ & Akhir bulan Juli & $6 \mathrm{minggu}$ \\
\hline 5. & $\begin{array}{l}\text { Penerbitan Surat Edaran Kepala Daerah perihal Pedoman } \\
\text { Penyusunan RKA-SKPD dan RKA-PPKD }\end{array}$ & Awal bulan Agustus & \\
\hline 6. & $\begin{array}{l}\text { Penyusunan dan pembahasan RKA-SKPD dan RKA- } \\
\text { PPKD serta penyusunan Rancangan Perda tentang APBD }\end{array}$ & $\begin{array}{l}\text { Awal bulan Agustus } \\
\text { sampai akhir bulan } \\
\text { September }\end{array}$ & 8 minggu \\
\hline 7. & $\begin{array}{l}\text { Penyampaian Rancangan Perda tentang APBD kepada } \\
\text { DPRD }\end{array}$ & $\begin{array}{l}\text { Minggu pertama } \\
\text { bulan Oktober }\end{array}$ & \\
\hline 8. & $\begin{array}{l}\text { Pengambilan persetujuan bersama DPRD dan Kepala } \\
\text { Daerah }\end{array}$ & $\begin{array}{lr}\text { Paling lama } 1 & \text { (satu) } \\
\text { bulan sebelum } & \text { tahun } \\
\text { anggaran } & \text { yang } \\
\text { bersangkutan } & \\
\end{array}$ & 2 bulan \\
\hline 9. & $\begin{array}{l}\text { Penyampaian Rancangan Perda tentang APBD dan } \\
\text { Rancangan Perda tentang penjabaran APBD kepada } \\
\text { MDN/Gubernur untuk dievaluasi }\end{array}$ & $\begin{array}{l}3 \text { hari kerja setelah } \\
\text { persetujuan bersama }\end{array}$ & \\
\hline 10. & $\begin{array}{l}\text { Hasil evaluasi Rancangan Perda tentang APBD dan } \\
\text { Rancangan Perda tentang Penjabaran APBD }\end{array}$ & $\begin{array}{l}\text { Paling lama } 15 \text { hari } \\
\text { kerja setelah } \\
\text { Rancangan Perda } \\
\text { tentang APBD dan } \\
\text { Rancangan Perda } \\
\text { tentang Penjabaran } \\
\text { APBD diterima oleh } \\
\text { MDN/Gubernur }\end{array}$ & \\
\hline
\end{tabular}

Sumber: Permendagri Nomor 13 Tahun 2006

\section{KESIMPULAN DAN SARAN}

\subsection{Kesimpulan}

1. Perencanaan Anggaran Pendapatan dan Belanja Daerah (APBD)

Proses perencanaan untuk Anggaran Pendapatan dan Belanja Daerah di Kabupaten Kepulauan Sangihe dalam hal ini difasilitasi oleh Badan Keuangan Daerah setempat sudah baik. Tahap awal dari penyusunan APBD yaitu Penyusunan Rencana Kerja Pemerintah Daerah (RKPD) yang didalamnya terdiri dari Persiapan Penyusunan RKPD, Penyusunan Rancangan Awal RKPD, Penyusunan Rancangan RKPD, Pelaksanaan Musrenbang RKPD, Perumusan Rancangan Akhir RKPD, Penetapan RKPD oleh Satuan Kerja Pemerintah Daerah (SKPD) ditiap instansi yang ada dinilai sudah berjalan baik. Namun ada tahap-tahap yang perlu diperhatikan konsistensi dan sasarannya agar tetap berkualitas sesuai dengan kebutuhan pembangunan daerah dan kesejahteraan masyarakat, misalkan proses Musyawarah Perencanaan Pembangunan (Musrenbang) dari tingkat kelurahan hingga kecamatan seringkali dilaksanakan hanya untuk formalitas. Hal ini mempengaruhi kesimpulan Musrenbang ditiap tingkatnya, artinya jika Musrenbang dilakukan hanya sekedarnya untuk formalitas, informasi yang terangkum dari kegiatan Musrenbang tersebut tidak bisa menjamin kualitasnya, mengingat mungkin saja programprogram pemerintah daerah yang diperolehdari Musrenbang yang seperti itu sarat akan politik para pemimpin tidak murni suara aspirasi masyarakat. 
2. Penganggaran Anggaran Pendapatan dan Belanja Daerah (APBD)

Dokumen Rancangan APBD (RAPBD) yang akan di evaluasi untuk disetujui menjadi dokumen APBD Tahun Anggaran 2015 dalam Sidang Paripurna mengalami keterlambatan waktu 8 hari dari waktu yang ditetapkan. Padahal jika dilihat, pengambilan keputusan antara DPRD dan Bupati untuk menyetujui dokumen RAPBD ditingkat daerah untuk persiapan dibahas pada Sidang Paripurna sudah tepat waktu. Ini disebabkan pemerintah daerah Kabupaten Kepulauan Sangihe terlambat memasukan dokumen RAPBD kepada pemerintah provinsi karena kurangnya koordinasi dan integritas waktu.

\subsection{Saran}

1. Perencanaan Anggaran Pendapatan dan Belanja Daerah (APBD)

Proses Musrenbang ditingkat kelurahan hingga kecamatan di Kabupaten Kepulauan Sangihe bukan hanya dilaksanakan sesuai jadwal yang ditetapkan tapi kualitas hasil Musrenbang ditiap tingkatnya harus sesuai dengan kebutuhan pembangunan daerah dan kesejahteraan masyarakat. Salah satu cara agar kualitas hasil Musrenbang baik adalah dengan menyediakan fasilitator Musrenbang yang berkualitas dalam wawasan dan berintegritas. Di Kabupaten Kepulauan Sangihe masih banyak kelurahan atau desa pedalaman yang memiliki perangkat desa yang masih terbatas dalam wawasan, penguasaan teknologi, dan lain-lain. Agar proses perencanaan baik secara keseluruhan, pemerintah bukan hanya memfasilitasi Musrenbang lewat surat edaran tapi juga ada dilapangan contohnya ketersediaan fasilitator Musrenbang. Untuk masalah keterkaitan antara dokumen RPJMD dan dokumen Rencana Strategis SKPD, Bappeda harap dapat menyediakan tenaga kerja yang mampu memberikan asistensi kepada SKPD dalam penyusunan rencana.

2. Penganggaran Anggaran Pendapatan dan Belanja Daerah (APBD)

Pemerintah Kabupaten Kepulauan Sangihe lebih memperhatikan koordinasi dan ketepatan waktu pemasukan dokumen Rancangan APBD (RAPBD). Setelah dokumen RAPBD telah disepakati ditingkat daerah sebaiknya langsung dimasukan kepada pemerintah Provinsi, mengingat Daerah Kabupaten/Kota yang juga akan mengevaluasi dokumen RAPBD pada Sidang Paripurna Provinsi Sulawesi Utara.

\section{DAFTAR PUSTAKA}

Bragg, S., 2014, Penganggaran (Budgeting): Panduan Komprehensif, Indeks, Jakarta.

Deddi, Iswahyudi, Maulidah, 2012, Akuntansi Pemerintahan, Salemba Empat, Jakarta.

Effendi, R., 2015, Accounting Principles: Prinsip-Prinsip Akuntansi Berbasis Sak Etap, Rajagrafindo Persada, Jakarta.

Korompot, R., 2015, Analisis Penyusunan Anggaran pada Dinas Pendapatan, Pengelolaan Keuangan dan Aset Daerah Kota Kotamobagu Tahun Anggaran 2014, Jurnal EMBA, Vol.3 No.1, 841-848.

Mardiasmo, 2014, Akuntansi Keuangan Dasar 1, BPFE, Yogyakarta

Pekei, B., 2016, Konsep dan Analisa Efektivitas Pengelolaan Keuangan Daerah di Era Otonomi, Taushia, Jakarta.

Ratmono, Sholihin, 2015, Akuntansi Keuangan Daerah Berbasis Akrual, UPP STIM YKPN, Yogyakarta.

Suwaryono, E., 2014, Rembug Anggaran dalam Perencanaan Penganggaran Daerah: Gabus Utawi Sae-Saen (Studi Kasus dalam Penganggaran Daerah di Pemerintah Kabupaten Boyolali), Universitas Muhammadiyah Surakarta, Tanggal akses 10 November 2017, http://eprints.ums.ac.id/32081/9/02.\%20Naskah\%20Publikasi.pdf. 
Pemerintah Republik Indonesia, Permendagri Nomor 13 tahun 2006 tentang Peraturan Pengelolaan Keuangan Daerah.

Pemerintah Kabupaten Kepulauan Sangihe, Peraturan Daerah No.15 tahun 2008 tentang organisasi dan tata kerja Dinas Daerah Kabupaten Kepulauan Sangihe.

Pemerintah Republik Indonesia, Permendagri Nomor 37 Tahun 2014 tentang pedoman penyusunan APBD tahun anggaran 2015.

Pemerintah Kabupaten Kepulauan Sangihe, Peraturan Daerah No. 10 Tahun 2014 tentang 